\title{
Peningkatkan Kemampuan Berpikir Kritis dan Hasil Belajar Matematika Materi Program Linear Melalui Model Pembelajaran Kontura Pada Siswa Kelas XI IIA MAN Karanggede
}

\author{
Erma Hidayati Choiriyah
}

\begin{abstract}
MAN Karanggede, Dukuh Klencong 01/01, Desa Pengkol, Kecamatan Karanggede, Kabupaten Boyolali
\end{abstract}

\begin{abstract}
This study aims to improve Critical Thinking Ability and mathematics learning outcomes of linear program material through the KONTURA learning model in class XI IIA MAN Karanggede in semester 1 academic year 2017/2018. The KONTURA Learning Model is a combination of Contextual Learning Models and Peer Tutors and uses of GeoGebra. The type of research was Classroom Action Research conducted in two cycles with research subjects were 25 students consisted of 9 male and 16 female. Data collection techniques used were observation, documentation, tests and questionnaires. Data analysis used included qualitative data analysis, namely data reduction, data presentation, and conclusion, as well as quantitative data analysis, namely the assessment of Critical Thinking Ability and peer observation of the implementation of the KONTURA learning.

The results of this study indicated the increase of Critical Thinking Ability and Mathematics student learning outcomes through the KONTURA learning model. Improvement of Critical Thinking Ability could be seen from the results of the Critical Thinking Ability questionnaire with the following results: There were 3 students (12\%) with High Critical Thinking Ability. After the implementation of the KONTURA learning model, there were 22 students (88\%) with High Critical Thinking Ability. The increase was 76\%. Students' learning outcomes also increased after applying the KONTURA learning model. In the beginning, there was no student who had very good or good grades. After applying the KONTURA learning model, students' learning outcomes increased. The number of students who had very high score was 1 student or 4\%, whereas the number of students whose score well was 5 students or $20 \%$. It increased $24 \%$.
\end{abstract}

Keywords: critical thinking ability, KONTURA learning model, mathematics, and mathematics learning outcomes.

\section{Pendahuluan}

Pendidikan memberikan kontribusi yang sangat besar terhadap kemajuan suatu bangsa. Melalui pendidikan maka bangsa Indonesia bisa membebaskan diri dari kebodohan, keterbelakangan, dan dapat mengembangkan sumber daya manusia sehingga dapat menambah percaya diri untuk bersaing dengan negaranegara lain. Pendidikan yang dikembangkan adalah pendidikan yang dapat mengembangkan potensi masyarakat, mampu menumbuhkan kemauan serta bisa membangkitkan kemampuan berpikir kritis untuk menggali potensi dan mengembangkannya secara optimal untuk membangun secara utuh dan menyeluruh.

Berpikir merupakan salah satu aktivitas mental yang tidak dapat dipisahkan dari kehidupan manusia. Kemampuan berpikir kritis setiap individu berbeda antara satu dengan lainnya sehingga perlu dipupuk sejak dini. Berpikir terjadi dalam setiap aktivitas mental manusia berfungsi untuk memformulasikan atau menyelesaikan masalah, membuat keputusan serta mencari alasan. Berpikir kritis merupakan sebuah kemampuan yang dimiliki setiap orang untuk menganalisis ide atau sebuah gagasan ke arah yang lebih spesifik untuk mengejar pengetahuan yang 
relevan tentang dunia dengan melibatkan evaluasi bukti. Kemampuan berpikir kritis sangat diperlukan untuk menganalisis suatu permasalahan sampai pada tahap pencarian solusi.

Kemampuan berpikir kritis sangat diperlukan untuk menghadapi tantangan global dan berbagai permasalahan kehidupan. Dengan kemampuan berpikir kritis seseorang dapat membedakan sisi positif dan negatif, kemudian menyaring berbagai pengaruh yang masuk dan menyesuaikannya dengan budaya bangsa Indonesia. menunjukkan pentingnya pengembangan kemampuan berpikir kritis, terutama dalam dunia pendidikan. Berdasarkan observasi yang dilakukan peneliti di MAN Karanggede Kab. Boyolali, terlihat bahwa kemampuan berpikir kritis siswa masih kurang (rendah), terutama dapat dilihat pada siswa kelas XI IIA. Kemampuan berpikir kritis siswa kelas XI IIA MAN Karanggede Kab. Boyolali dapat dilihat dari berbagai hal, misalnya berdasarkan pengamatan saat kegiatan pembelajaran matematika berlangsung, siswa hanya sekedar melihat guru menjelaskan, sesekali mencatat hal-hal penting, tetapi jika ditanya kembali mengenai apa yang dijelaskan guru, mereka masih sulit menjelaskan kembali dengan menggunakan bahasa mereka sendiri. Demikian juga hasil belajar siswa kelas XI IIA MAN Karanggede Kab. Boyolali masih rendah, hal itu dapat dilihat dari hasil penilaian harian.

Berdasar pengamatan peneliti dan diskusi dengan guru matematika di MAN Karanggede Kab. Boyolali dijumpai sulitnya membelajarkan matematika. Siswa banyak mengalami keluhan karena kesulitan memahami konsep matematika. Termasuk membelajarkan materi Program Linear yang merupakan bagian dari materi matematika di kelas XI IPA. Materi tersebut berkaitan dengan pemecahan masalah sehari-hari algoritma dan gambar yang rumit, sehingga wajar apabila siswa mengalami kesulitan mempelajarinya.

Guna menunjang membelajarkan materi Program Linear, diperlukan suatu cara pembelajaran dan lingkungan yang kondusif bagi perkembangan kemampuan tersebut serta media pembelajaran yang cocok semisal pemanfaatan GeoGebra. Sehingga pembelajaran matematika dari yang dirasa rumit menjadi lebih mudah dengan demikian dapat merangsang siswa untuk belajar mandiri, kreatif, dan lebih aktif dalam mengikuti kegiatan pembelajaran. Peneliti mengambil judul: "Peningkatkan Kemampuan Berpikir Kritis dan Hasil Belajar Matematika Materi Program Linear Melalui Model Pembelajaran KONTURA pada Siswa Kelas XI IIA MAN Karanggede Kab. Boyolali Semester 1 Tahun Pelajaran 2017/2018".

\section{Kajian Teori}

\section{Kemampuan Berpikir Kritis}

Kemampuan berpikir kritis merupakan sebuah proses yang terarah dan jelas yang digunakan dalam kegiatan mental seperti memecahkan masalah, mengambil keputusan, membujuk, menganalisis asumsi, dan melakukan penelitian ilmiah. Pengertian berpikir kritis, menurut Ennis dan Costa dalam Suryadi dan Herman, (2008: 20) merupakan suatu proses penggunaan kemampuan berpikir secara efektif yang dapat membantu seseorang untuk membuat, mengevaluasi serta mengambil keputusan tentang apa yang diyakini atau dilakukan. Menurut Johnson (2014: 187) berpikir kritis adalah berpikir dengan baik, dan merenungkan tentang proses berpikir merupakan bagian dari berpikir dengan baik. 
Menurut Santrock (2011: 359), pemikiran kritis adalah pemikiran reflektif dan produktif, dan melibatkan evaluasi bukti. Jensen (2011: 195) berpendapat bahwa berpikir kritis berarti proses mental yang efektif dan handal, digunakan dalam mengejar pengetahuan yang relevan dan benar tentang dunia. Cece Wijaya (2010: 72) juga mengungkapkan gagasannya mengenai kemampuan berpikir kritis, yaitu kegiatan menganalisis ide atau gagasan ke arah yang lebih spesifik, membedakannya secara tajam, memilih, mengidentifikasi, mengkaji dan mengembangkannya ke arah yang lebih sempurna.

Menurut Halpen dalam Achmad memberdayakan ketrampilan atau strategi kognitif dalam menentukan tujuan. Proses tersebut dilalui setelah menentukan tujuan, mempertimbangkan, dan mengacu langsung kepada sasaran-merupakan bentuk berpikir yang perlu dikembangkan dalam rangka memecahkan masalah, merumuskan kesimpulan, mengumpulkan berbagai kemungkinan, dan membuat keputusan ketika menggunakan semua keterampilan tersebut secara efektif dalam konteks dan tipe yang tepat.

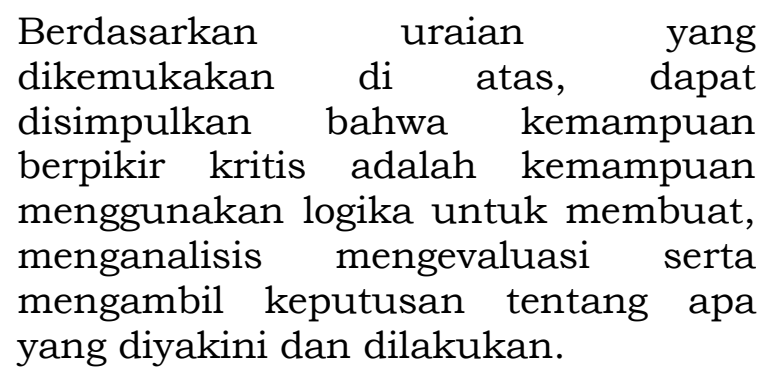

Tujuan pembelajaran meningkatkan kemampuan berpikir kritis adalah agar siswa mampu berpikir netral, obyektif, beralasan atau logis. Menurut Sanjaya, seorang disebut sebagai pemikir kritis jika berusaha menganalisis argumentasi secara cermat, mencari bukti yang sah, dan menghasilkan kesimpulan yang mantap untuk mempercayai dan melakukan sesuatu. Pemikir kritis akan memiliki kecenderungan untuk mencari kejelasan suatu masalah dan alasannya, bersifat terbuka, dan memperhatikan situasi keseluruhan dan mencari alternatif (Darmawan, 2010: 109).

\section{Hasil Belajar Matematika}

Matematika berdasarkan pendapat Susanto (2013: 185) adalah salah satu disiplin ilmu pasti yang mengungkapkan ide-ide abstrak yang berisi bilangan-bilangan serta simbol-simbol operasi hitung yang terdapat aktivitas berhitung dan mampu meningkatkan kemampuan berpikir dan berpendapat dalam memecahkan masalah kehidupan bermasyarakat sehari-hari. Johson dan Myklebust dalam Sundayana (2003: 252) mengemukakan bahwa matematika merupakan bahasa simbolis yang mempunyai fungsi praktis untuk mengekspresikan hubungan kuantitatif dan keruangan.

Hamalik (2003: 27) mendefinisikan belajar sebagai: (1) modifikasi atau memperteguh kelakuan melalui pengakuan, (2) suatu proses perubahan tingkah laku individu melalui interaksi dengan lingkungan. Slameto (2010: 2) mengungkapkan bahwa belajar adalah suatu proses usaha yang dilakukan seseorang untuk memperoleh suatu perubahan tingkah laku yang baru secara keseluruhan, sebagai hasil pengalamannya sendiri dalam interaksi dengan lingkungannya.

Hasil belajar diartikan sebagai hasil akhir pengambilan keputusan tentang tinggi rendahnya nilai siswa selama mengikuti proses belajar mengajar, pembelajaran dikatakan berhasil jika tingkat pengetahuan siswa bertambah dari hasil sebelumnya (Djamarah, 2000: 25).

Dari beberapa pendapat di atas, dapat disimpulkan bahwa hasil belajar matematika adalah suatu proses perubahan tingkah laku individu yang 
mengakibatkan bertambahnya pengetahuan, keterampilan, dan nilai sikap yang berkaitan dengan konsep-konsep abstrak, fakta, keterampilan, konsep, dan aturan yang diperoleh melalui interaksi individu dengan guru dan lingkungannya.

\section{Model Pembelajaran KONTURA}

Model pembelajaran digunakan dalam upaya untuk meningkatkan mutu pembelajaran. Komalasari (2010: 57) model pembelajaran pada dasarnya merupakan bentuk pembelajaran yang tergambar dari awal sampai akhir yang disajikan secara khas oleh guru. Dengan kata lain model pembelajaran merupakan bungkus atau bingkai dari penerapan suatu pendekatan metode dan teknik pembelajaran.

Arends (dalam Suprijono, 2009: 46) model pembelajaran mengacu pada pendekatan yang akan digunakan, termasuk di dalamnya tujuan pembelajaran, tahap-tahap dalam kegiatan pembelajaran, lingkungan pembelajaran, dan pengelolaan kelas.

Leo Agung dan Sri Wahyuni (2013: 66) menjelaskan secara spesifik pengertian model dikaitkan dengan pembelajaran. Model pembelajaran adalah kesatuan yang utuh antara pendekatan, strategi metode teknik dan taktik pembelajaran terangkai menjadi kesatuan.

Menurut Joyce \& Weil model pembelajaran adalah suatu cara membantu siswa memperoleh informasi, gagasan, skill, nilai, cara berpikir, dan tujuan mengekspresikan diri mereka sendiri (2009: 7). Berdasarkan pendapat para ahli di atas, maka dapat disimpulkan bahwa model pembelajaran adalah bentuk pembelajaran yang tergambar dari awal sampai akhir yang disajikan secara khas oleh guru dalam merencanakan pembelajaran di kelas untuk meningkatkan kemampuan siswa secara optimal guna mencapai tujuan pembelajaran yang diinginkan.

Model Pembelajaran KONTURA adalah gabungan antara Model Kontekstual dan Tutor Sebaya serta menggunakan media GeoGebra.

Tabel 1. Sintaks Model Pembelajaran KONTURA

\begin{tabular}{|c|c|}
\hline Tahap & Aktivitas Guru \\
\hline $\begin{array}{l}\text { Penda- } \\
\text { huluan }\end{array}$ & $\begin{array}{l}\text { 1. Guru mengingatkan siswa } \\
\text { mengenai materi pertidak- } \\
\text { samaan linear dua variabel } \\
\text { dan cara menggambar } \\
\text { daerah penyelesaian materi } \\
\text { pertidaksamaan linear dua } \\
\text { variabel (Contructivisme) }\end{array}$ \\
\hline $\begin{array}{l}\text { Kegiatan } \\
\text { Inti }\end{array}$ & $\begin{array}{l}\text { 2. Guru membagi siswa } \\
\text { dalam } 5 \text { kelompok yang } \\
\text { dipilih secara heterogen } \\
\text { dan dipimpin oleh tutor } \\
\text { sebaya (Menciptakan } \\
\text { masyarakat belajar atau } \\
\text { learning community). } \\
\text { 3. Guru membagikan materi } \\
\text { tentang Program Linear } \\
\text { dan contoh-contoh soal } \\
\text { Program Linear kepada } \\
\text { setiap kelompok. } \\
\text { 4. Guru membagikan Lembar } \\
\text { Kerja dan memperagakan } \\
\text { media GeoGebra untuk } \\
\text { menyelesaikan soal-soal } \\
\text { Program Linear (modeling). } \\
\text { 5. Guru memberi kesempatan } \\
\text { kepada salah satu kelom- } \\
\text { pok untuk membacakan } \\
\text { hasil diskusi kelompoknya. }\end{array}$ \\
\hline Penutup & $\begin{array}{l}\text { 6. Guru memberikan pesan- } \\
\text { pesan positif sehubungan } \\
\text { dengan masalah yang } \\
\text { didiskusikan } \\
\text { 7. Guru memberikan pos tes } \\
\text { kepada siswa }\end{array}$ \\
\hline
\end{tabular}

\section{Metode Penelitian}

Penelitian ini dilaksanakan pada semester ganjil tahun pelajaran $2017 / 2018$ dimulai pada bulan Agustus sampai November 2017.

Tempat yang digunakan untuk penelitian adalah MAN Karanggede Kab. Boyolali kelas XI IIA tahun ajaran 2017/2018. MAN Karanggede terletak di Kecamatan Karanggede, Kab. Boyolali. 
Subjek penelitian ini adalah siswa kelas XI IIA MAN Karanggede Kab. Boyolali, dengan jumlah siswa 25 anak yang terdiri dari 9 laki-laki dan 16 perempuan

Objek penelitian yang digunakan adalah penerapan model pembelajaran KONTURA.

Sumber data Kemampuan Berpikir Kritis belajar siswa saat model pembelajaran KONTURA diterapkan yaitu dari siswa kelas XI IIA yang diperoleh melalui angket.

Sumber data hasil belajar siswa sebelum dilakukan PTK yaitu dari guru mata pelajaran Matematika yang diperoleh melalui kajian dokumen nilai penilaian harian siswa. Sedangkan sumber data hasil belajar siswa saat model pembelajaran KONTURA diterapkan yaitu dari siswa kelas XI IIA yang diperoleh melalui nilai ulangan siswa pada materi Program Linear.

Sumber data kualitatif proses pembelajaran dengan model pembelajaran KONTURA diperoleh melalu observasi yang dilakukan teman sejawat.

Indikator keberhasilan penelitian ini adalah apabila terjadi peningkatan kemampuan berpikir kritis dan hasil belajar siswa ketika model pembelajaran KONTURA diterapkan.

Tabel 2. Ukuran Keberhasilan Penelitian

\begin{tabular}{lll}
\hline \multicolumn{1}{c}{$\begin{array}{c}\text { Ukuran } \\
\text { Keberhasilan }\end{array}$} & \multicolumn{1}{c}{ Target } & $\begin{array}{c}\text { Teknik } \\
\text { Pengumpulan } \\
\text { Data }\end{array}$ \\
\hline Hasil & Minimal 85\% hasil & Tes formatif \\
Siswa & ulangan siswa & \\
& mencapai Kriteria & \\
& Ketuntasan Minimal & \\
(KKM) yaitu 75 & \\
\hline Kemampu- & Minimal 80\% siswa & Angket \\
Kritis Siswa & menunjukkan & \\
& kemampuan berpikir & \\
& kembelajaran & \\
& matematika dengan & \\
& kategori tinggi & \\
\hline
\end{tabular}

\section{Hasil Tindakan Penelitian Dan Pembahasan Deskripsi Prasiklus}

Kondisi kelas XI IIA sebelum penelitian dilakukan diketahui bahwa pelaksanaan pembelajaran pada prasiklus dilakukan dengan penerapan metode diskusi kelompok. Dari penerapan metode diskusi kelompok tersebut ternyata kemampuan berpikir kritis pada prasiklus kurang baik, hasil dari pengamatan kemampuan berpikir kritis siswa pada proses pembelajaran prasiklus menunjukkan bahwa kemampuan berpikir kritis tinggi ada 3 siswa (12\%), sedang ada 21 siswa (84\%) dan rendah ada 1 siswa (4\%).

Sebelum penelitian dilakukan bahwa pada Pra-Siklus Hasil Belajar siswa pada mapel Matematika oleh siswa kelas XI IIA Semester 1 tahun pelajaran 2017/2018 masih rendah, hal ini dapat dilihat dari hasil Penilaian harian pada materi sistem pertidaksamaan linear dua variabel dengan KKM 75. Hasil Penilaian harian pada materi sistem pertidaksamaan linear dua variabel siswa kelas XI IIA, tidak ada siswa yang memperoleh nilai sangat baik atau baik (0\%), 8 (delapan) atau 32\% siswa memperoleh nilai cukup, dan 17 siswa atau 68\% siswa memperoleh nilai kurang.

Berdasarkan kondisi kemampuan berpikir kritis pada prasiklus yang kurang baik dan Hasil Belajar siswa pada mapel Matematika oleh siswa kelas XI IIA Semester 1 tahun pelajaran 2017/2018 masih rendah, maka perlu dilakukan tindakan perbaikan, yaitu penerapan metode pembelajaran yang dipandang dapat meningkatkan Kemampuan Berpikir Kritis dan hasil belajar siswa. Adapun model pembelajaran yang diterapkan dalam tindakan ini adalah Model Pembelajaran KONTURA. 


\section{Deskripsi Siklus I}

Hasil dari angket kemampuan berpikir kritis siswa setelah proses pembelajaran siklus I dapat dilihat pada tabel berikut.

Tabel 3. Data Hasil Angket Kemampuan Berpikir Kritis Belajar Siswa Kelas XI IIA Siklus I

\begin{tabular}{lcc}
\hline $\begin{array}{c}\text { Kategori } \\
\text { Kemampuan } \\
\text { Berpikir Kritis }\end{array}$ & Jumlah & Persentase \\
\hline Tinggi & 15 & $60 \%$ \\
\hline Sedang & 10 & $40 \%$ \\
\hline Rendah & 0 & $0,0 \%$ \\
\hline
\end{tabular}

Setelah proses pembelajaran siklus I selesai, dilakukan pengukuran Hasil Belajar melalui tes tertulis dalam bentuk uraian sebanyak 5 soal esai. Hasil belajar siklus I dipaparkan pada tabel berikut.

Tabel 4. Data Hasil Belajar Siswa Kelas XI IIA Siklus I

\begin{tabular}{cccc}
\hline $\begin{array}{c}\text { Interval } \\
\text { Nilai }\end{array}$ & Keterangan & $\mathrm{Jml}$ & $\begin{array}{c}\text { Persen- } \\
\text { tase }\end{array}$ \\
\hline $92-100$ & Sangat Baik & 0 & $0,0 \%$ \\
\hline $83-92$ & Baik & 1 & $4,0 \%$ \\
\hline $75-83$ & Cukup & 15 & $60,0 \%$ \\
\hline$<75$ & Kurang & 9 & $36,0 \%$ \\
\hline $\begin{array}{l}\text { Berdasarkan hasil observasi terhadap } \\
\text { kinerja guru selama }\end{array}$ & $\begin{array}{c}\text { proses } \\
\text { pembelajaran siklus I, hasilnya seperti } \\
\text { terlihat pada tabel berikut. }\end{array}$
\end{tabular}

Tabel 5. Data Hasil Pengamatan Teman Sejawat Model Pembelajaran KONTURA Siklus I

\begin{tabular}{lc}
\hline Kegiatan Guru & Siklus I \\
\hline Memberi salam, berdoa' dan membaca & 3 \\
Al'Qur'an selama 15 menit untuk & \\
kelas yang masuk di jam pertama & \\
\hline $\begin{array}{l}\text { Mengkondisikan suasana belajar yang } \\
\text { menyenangkan dan mengecek }\end{array}$ & 3 \\
kehadiran peserta didik & 3 \\
\hline $\begin{array}{l}\text { Melalui tanya jawab membahas } \\
\text { kompetensi yang sudah dipelajari dan } \\
\text { dikembangkan sebelumnya berkaitan } \\
\text { dengan materi pertidak-samaan linear }\end{array}$ & \\
\hline
\end{tabular}

\begin{tabular}{ll}
\hline dua variabel; (Contructivisme) & 3 \\
\hline $\begin{array}{l}\text { Menyampaikan kompetensi yang akan } \\
\text { dicapai dan manfaat program linear } \\
\text { dalam kehidupan sehari-hari }\end{array}$ & \\
\hline $\begin{array}{l}\text { Menyampaikan garis besar cakupan } \\
\text { materi program linear dan kegiatan }\end{array}$ & 2 \\
yang akan dilakukan & \\
\hline $\begin{array}{l}\text { Menyampaikan metode pembelajaran } \\
\text { dan teknik penilaian yang akan } \\
\text { digunakan saat membahas materi } \\
\text { program linear }\end{array}$ & 2 \\
\hline $\begin{array}{l}\text { Guru membagi siswa dalam 5 } \\
\text { kelompok yang dipilih secara } \\
\text { heterogen dan dipimpin oleh tutor } \\
\text { sebaya. (menciptakan masyarakat } \\
\text { belajar atau learning community) }\end{array}$ \\
\hline $\begin{array}{l}\text { Guru memfasilitasi siswa mempelajari } \\
\text { materi tentang Program Linear dan } \\
\text { contoh-contoh soal Program Linear }\end{array}$ \\
$\begin{array}{l}\text { untuk menemukan pengetahuan baru } \\
\text { dan menambah pengalamannya yang } \\
\text { dipandu tutor sebaya (inquiry). }\end{array}$ \\
\hline $\begin{array}{l}\text { Guru membagikan Lembar Kerja dan } \\
\text { memperagakan media GeoGebra }\end{array}$ \\
$\begin{array}{l}\text { untuk menyelesaikan soal-soal } \\
\text { Program Linear (modeling) }\end{array}$ \\
\hline $\begin{array}{l}\text { Guru memberi kesempatan kepada } \\
\text { salah satu kelompok untuk } \\
\text { membacakan hasil diskusi } \\
\text { kelompoknya }\end{array}$ \\
\hline $\begin{array}{l}\text { Guru memberikan penghargaan } \\
\text { kepada kelompok yang berkinerja } \\
\text { baik, nasehat bagi kelompok yang } \\
\text { kurang baik }\end{array}$ \\
\hline $\begin{array}{l}\text { Guru memberikan pesan-pesan positif } \\
\text { didiskusikan }\end{array}$ \\
refleksi dan menarik kesimpulan \\
pertemuan berikutnya yaitu penilaian \\
\hline
\end{tabular}

Kemampuan berpikir kritis belajar siswa dan hasil belajar siswa pada proses tindakan siklus I diperoleh hasil dirasa masih bisa dimaksimalkan, karena ditemukan 16 atau $64 \%$ siswa menunjukkan kemampuan berpikir kritis tinggi. Angka ini masih di bawah indikator keberhasilan yaitu 80\%. Demikian juga dengan hasil belajar. Ditemukan 16 atau 64\% siswa masih di bawah indikator keberhasilan. Oleh sebab itu perlu dilakukan tindak lanjut yaitu dengan penerapan model pembelajaran KONTURA pada siklus II dengan memperbaiki kelemahan dan 
kekurangan yang terjadi pada siklus I sehingga pada akhirnya diperoleh peningkatan yang lebih optimal.

\section{Deskripsi Siklus II}

Setelah penerapan model KONTURA pada siklus II diperoleh data Kemampuan Berpikir Kritis belajar sebagai berikut.

Tabel 6. Data Hasil Angket Kemampuan Berpikir Kritis Siswa Kelas XI IIA Siklus II

\begin{tabular}{lcc}
\hline $\begin{array}{c}\text { Kategori Kemampuan } \\
\text { Berfikir Kritis }\end{array}$ & Jumlah Persentase \\
\hline Tinggi & 22 & $88,0 \%$ \\
\hline Sedang & 3 & $12,0 \%$ \\
\hline Rendah & 0 & $0,0 \%$ \\
\hline
\end{tabular}

Hasil belajar siswa pada siklus II dipaparkan pada tabel berikut.

Tabel 7. Data Hasil Belajar Siswa Kelas XI IIA Siklus II

\begin{tabular}{clcc}
\hline $\begin{array}{c}\text { Interval } \\
\text { Nilai }\end{array}$ & Keterangan & \multicolumn{2}{c}{ JumlahPersentase } \\
\hline $92-100$ & Sangat Baik & 1 & $4,0 \%$ \\
\hline $83-92$ & Baik & 5 & $20,0 \%$ \\
\hline $75-83$ & Cukup & 18 & $72,0 \%$ \\
\hline$<75$ & Kurang & 1 & $4,0 \%$ \\
\hline
\end{tabular}

Berdasarkan hasil observasi terhadap kinerja guru selama proses pembelajaran siklus II, hasilnya seperti terlihat pada tabel berikut.

Tabel 8. Kinerja guru dalam menerapkan model pembelajaran KONTURA pada kegiatan Siklus II

\begin{tabular}{lc}
\hline Kegiatan Guru & Siklus II \\
\hline Memberi salam, berdoa dan membaca & 4 \\
$\begin{array}{l}\text { Al Qur'an selama 15 menit untuk } \\
\text { kelas yang masuk di jam pertama }\end{array}$ & \\
\hline $\begin{array}{l}\text { Mengkondisikan suasana belajar } \\
\text { yang menyenangkan dan mengecek } \\
\text { kehadiran peserta didik }\end{array}$ & 4 \\
\hline $\begin{array}{l}\text { Melalui tanya jawab membahas } \\
\text { kompetensi yang sudah dipelajari dan } \\
\text { dikembangkan sebelumnya berkaitan } \\
\text { dengan materi pertidak-samaan }\end{array}$ & 3 \\
linear dua variabel; (Contructivisme) & \\
\hline Menyampaikan kompetensi yang & 4 \\
\hline
\end{tabular}

\begin{tabular}{|c|c|}
\hline $\begin{array}{l}\text { akan dicapai dan manfaat program } \\
\text { linear dalam kehidupan sehari-hari }\end{array}$ & \\
\hline $\begin{array}{l}\text { Menyampaikan garis besar cakupan } \\
\text { materi program linear dan kegiatan } \\
\text { yang akan dilakukan }\end{array}$ & 3 \\
\hline $\begin{array}{l}\text { Menyampaikan metode pembelajaran } \\
\text { dan teknik penilaian yang akan } \\
\text { digunakan saat membahas materi } \\
\text { program linear }\end{array}$ & 3 \\
\hline $\begin{array}{l}\text { Guru membagi siswa dalam } 5 \\
\text { kelompok yang dipilih secara } \\
\text { heterogen dan dipimpin oleh tutor } \\
\text { sebaya. (menciptakan masyarakat } \\
\text { belajar atau learning community) }\end{array}$ & 4 \\
\hline $\begin{array}{l}\text { Guru memfasilitasi siswa mempelajari } \\
\text { materi tentang Program Linear dan } \\
\text { contoh-contoh soal Program Linear } \\
\text { untuk menemukan pengetahuan } \\
\text { baru dan menambah pengalamannya } \\
\text { yang dipandu tutor sebaya (inquiry). }\end{array}$ & 3 \\
\hline $\begin{array}{l}\text { Guru membagikan Lembar Kerja dan } \\
\text { memperagakan media GeoGebra } \\
\text { untuk menyelesaikan soal-soal } \\
\text { Program Linear (modeling) }\end{array}$ & 4 \\
\hline $\begin{array}{l}\text { Guru memberi kesempatan kepada } \\
\text { salah satu kelompok untuk } \\
\text { membacakan hasil diskusi } \\
\text { kelompoknya }\end{array}$ & 4 \\
\hline $\begin{array}{l}\text { Guru memberikan penghargaan } \\
\text { kepada kelompok yang berkinerja } \\
\text { baik, nasehat bagi kelompok yang } \\
\text { kurang baik }\end{array}$ & 3 \\
\hline $\begin{array}{l}\text { Guru memberikan pesan-pesan } \\
\text { positif sehubungan dengan masalah } \\
\text { yang didiskusikan }\end{array}$ & 4 \\
\hline $\begin{array}{l}\text { Guru membimbing siswa melakukan } \\
\text { refleksi dan menarik kesimpulan }\end{array}$ & 4 \\
\hline $\begin{array}{l}\text { Guru memberikan informasi kegiatan } \\
\text { pertemuan berikutnya yaitu penilaian } \\
\text { harian }\end{array}$ & 4 \\
\hline
\end{tabular}

Setelah penerapan model pembelajaran KONTURA didapatkan kemampuan berpikir kritis siswa pada siklus II mengalami peningkatan. Jika pada siklus I ada 15 siswa (60\%) maka pada siklus II diperoleh 22 siswa (88\%) memiliki kemampuan berpikir Kritis tinggi. Peningkatan signifikan juga diperoleh pada hasil belajar, dari 16 atau $64 \%$ siswa tuntas, setelah penerapan model pembelajaran KONTURA pada siklus II meningkat menjadi 24 atau 96\% siswa. Serta proses pembelajaran dengan menerapkan model pembelajaran KONTURA juga semakin baik, hasil pengamatan teman sejawat pada kegiatan guru mendapatkan penilaian 
baik atau baik sekali. Oleh karena itu penerapan model pembelajaran KONTURA bisa dikatakan dapat meningkatkan kemampuan berpikir kritis dan hasil belajar siswa serta kompetensi guru (lewat pengamatan teman sejawat). Pada proses tindakan siklus II hasil yang diperoleh siswa dirasa sudah maksimal, oleh sebab itu tidak perlu dilakukan tindak penelitian lanjutan.

\section{Pembahasan}

Berdasarkan hasil angket kemampuan berpikir kritis yang telah diisi siswa, kemampuan berpikir kritis belajar siswa setelah penerapan model pembelajaran KONTURA dapat meningkat dari kondisi awal ke kondisi akhir setelah siklus I dan dilanjutkan pada siklus II.

a. Kemampuan berpikir kritis kategori tinggi dari 3 siswa (12\%) pada prasiklus, naik menjadi 15 siswa (60\%) pada siklus I, dan naik lagi menjadi 22 siswa (88\%) pada siklus II.

b. Kemampuan berpikir kritis kategori sedang dari 21 siswa (84\%) pada prasiklus, turun menjadi 10 siswa (40\%) pada siklus I, dan turun lagi menjadi 3 siswa (12\%) pada siklus II.

c. Kemampuan berpikir kritis kategori rendah dari 1 siswa (4\%) pada Prasiklus, turun menjadi 0 siswa $(0 \%)$ pada siklus I, dan tetap 0 siswa (0\%) pada siklus II.

Berdasarkan hasil belajar setelah penerapan model pembelajaran KONTURA dapat meningkatkan dari kondisi awal ke kondisi akhir setelah siklus I dan dilanjutkan pada siklus II terdapat peningkatan untuk:

a. Jumlah siswa dengan nilai sangat baik, dari tidak ada siswa $(0 \%)$ pada prasiklus dan siklus I, meningkat menjadi 1 siswa (4\%) pada Siklus II.

b. Jumlah siswa dengan nilai Baik, dari tidak ada siswa (0\%) pada prasiklus, naik menjadi 1 siswa (4\%) pada siklus I dan naik lagi menjadi 5 siswa atau $20 \%$ pada Siklus II. c. Jumlah siswa dengan nilai cukup, dari 8 siswa (32\%) pada prasiklus, naik menjadi 15 siswa atau $60 \%$ pada siklus I dan naik lagi menjadi 18 siswa atau $72 \%$ pada Siklus II.

d. Jumlah siswa dengan nilai kurang, dari 17 siswa atau 68\% pada prasiklus, turun menjadi 9 siswa atau $36 \%$ pada siklus I dan turun lagi menjadi 1 siswa atau 4\% pada Siklus II.

\section{Simpulan dan Saran Simpulan}

Berdasarkan proses pembelajaran setelah penerapan model pembelajaran KONTURA dapat meningkatkan Kemampuan Berpikir Kritis belajar dan Hasil Belajar siswa kelas XI IIA Semester 1 MAN Karanggede Kab. Boyolali tahun pelajaran 2017/2018 pada Mapel Matematika materi Program Linear.

\section{Saran}

\section{Saran untuk Guru}

Bagi rekan guru, khususnya guru mata pelajaran Matematika SMA, penggunaan program GeoGebra pada materi program linear sangat efektif dan efisien dalam membantu siswa memahami materi dan menyelesaikan soal-soal program Linear. Gunakan media IT khususnya program GeoGebra untuk materi-materi yang lain, dengan pemanfaatan media IT siswa akan lebih senang dan semangat dalam mengikuti pelajaran di kelas.

\section{Saran untuk Siswa}

Bagi siswa yang akan mengikuti pembelajaran harus memperhatikan petunjuk serta arahan yang disampaikan oleh guru dalam pemanfaatan media IT khususnya program GeoGebra supaya hasil belajarnya dapat meningkat, sehingga menjadi siswa yang bertaqwa, beriman, berilmu, dan berbudi pekerti luhur sesuai dengan visi dan misi MAN Karanggede. 


\section{Daftar Pustaka}

Achmad, Arief. (2007). Memahami Berpikir Kritis. [Online]. Tersedia: http://researchengines.com/1007arief3.html [5 Februari 2010]

Cece Wijaya. (2010). Pendidikan Remidial: Sarana Pengembangan Mutu Sumber Daya Manusia. Bandung: PT Remaja Rosdakarya.

Darmawan. (2010). "Penggunaan pembelajaran berbasis masalah dalam meningkatkan kemampuan berpikir kritis siswa pada pembelajaran IPS di MI Darrusaadah Pandeglang”. Jurnal UPI Vol.11, No.2, Oktober 2010 (online)

Djamarah, Syaiful Bahri. (2000). Psikologi Belajar. Jakarta: Rineka Cipta.

Hamalik. (2003). Tahapan Pembelajaran Inkuiri terbimbing. Jakarta: Balai Pustaka.

Jensen Eric. (2011). Pembelajaran Berbasis Otak: Paradigma Pengajaran Baru. Jakarta: Indeks.

Johnson, B. Elaine. (2006). Contextual Teaching \& Learning. Terj. Ibnu Setiawan, Bandung: MLC.

Joyce, B., Weil, M., dan Calhoun, E. (2009). Model of Teaching. Yogyakarta: Pustaka Pelajar.

Santrock, John W. (2011). Perkembangan Anak Edisi 7 Jilid 2. (Terjemahan: Sarah Genis B) Jakarta: Erlangga

Slameto. (2010). Belajar dan faktor-faktor yang Mempengaruhinya, Edisi Revisi. Jakarta: Rineka Cipta

Sundayana, Rostina (2003) Media Pembelajaran matematika. Bandung: Alfabet.

Suprijono, Agus. (2009). Cooperative Learning Teori dan Aplikasi PAIKEM. Yogyakarta: Pustaka Pelajar

Suryadi, D. dan Herman, T. (2008). Eksplorasi Matematika Pembelajaran Pemecahan Masalah. Bekasi: Karya Duta Wahana.

Susanto, Hadi. (2013). Pembelajaran Tutor Sebaya. Diakses pada Tanggal 23 Maret 2015 pukul 15.40 di https://bagawanabiyasa.wordpress.com /2013/07/21/Pembelajarantutor sebaya/.html. 